DOI: $10.21625 /$ resourceedings.v1i1.184

\title{
EMBEDDING SUSTAINABILITY PRINCIPLES IN THE MINDSET OF CHILDREN THROUGH CREATING NATURE- INTERACTIVE PHYSICAL SPACES
}

\author{
Yasmin Sadek ${ }^{1}$, Laila Khodeir ${ }^{2}$ \\ ${ }^{1}$ Architect at center for planning and architectural studies company \\ ${ }^{2}$ Associate Professor at Ain Shams University and The British University in Egypt
}

\section{Keywords}

Sustainability, Biophilia, Educational spaces, Nature, Children, ISCDC project;

\begin{abstract}
The natural world is one of the most important factors that shape the maturity of children. However, the results of a recent survey that was conducted on 12,000 parents from 10 different countries showed that one third of children between the ages of 5 to 12 years spend less than 30 minutes outside every day. This survey and other relevant studies have highlighted the problem of the lack of childrens' interaction with their surrounding environment and nature in general. One of the major role players who can make a difference in resolving children-environment interaction is the architecture designer who is the one responsible for creating physical spaces for children. The objective of this paper is thus to investigate the role of architecture in the creation of spaces for children that can act as a tool in itself, which could promote both tangible and intangible sustainability concepts. A literature review was conducted in order to study the principles of sustainability and how to integrate nature into a physical space for children through a number of analyzed case studies. Findings of this paper were based on a double perception including literature and designers. It was indicated that children are generally interested in the idea of integrating nature to their physical space.
\end{abstract}

The results of this study are expected to influence architects through presenting guidelines that govern decisions throughout the design of spaces for children. It is recommended that such spaces should enhance the understanding of the concept of sustainability and could sustain sustainability in the mindset of young children who, in turn, represent an environmentally aware future generation.

\section{Introduction}

Sustainability became a substantial topic in the last few years all over the world where our global future relies on it. This is due to the rapid increase in numbers of inappropriate buildings built that destroy nature and causes overconsumption of natural resources. Sustainability is defined as the capability to fulfill the present needs without harming the environment, depleting natural resources and compromising the ability of future generations to meet their own needs (Roberston, 2014). Fig. (1) shows the three main pillars of sustainability: 


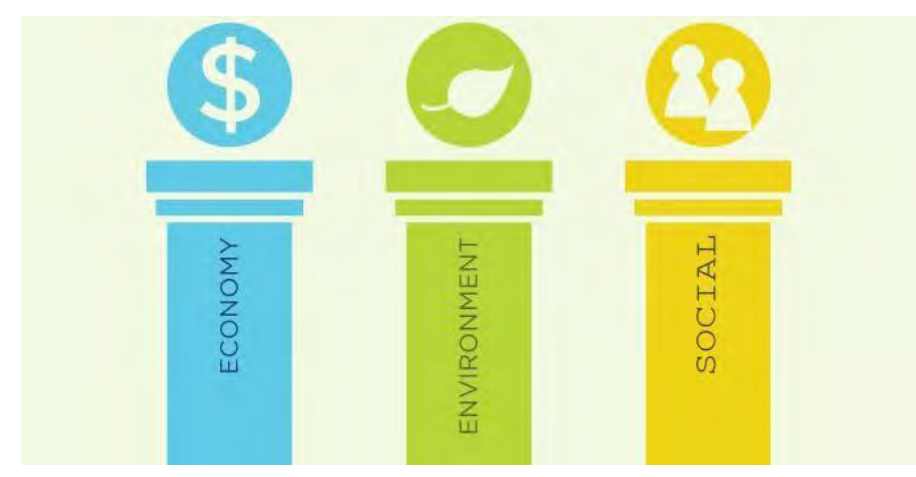

Figure 1: Sustainability 3 Main Pillars, (Hamdan, 2013)

In order to cover and apply all the points of sustainability, it is important to understand the meaning of each pillar. Firstly, environmental sustainability is to make use of the environmental resources for meeting the present human needs without reducing its capacity to permit people to live well, both now and in the future. Examples on environmental sustainability are consumption and production of energy, pollution and management of water and waste of food.

Social sustainability is the ability of developing processes and structures which meet the needs of the present people and also support the capability of the future generations in having healthy communities. Examples on social sustainability are the working and labor conditions, cultural heritage, health of community and social equity.

Finally, economic sustainability is applying different strategies for utilizing existing resources efficiently to achieve over the long term a responsible and beneficial balance. Examples on economic sustainability are minimizing the waste, steady economic growth and allocating resources equitably (Morris, 2016).

Although sustainability has been categorized into three pillars, the aspects of those pillars could be divided into 2 categories which are "tangible" and "intangible". Tangible is indisputably defined as the thing that is real and touchable, not imaginary and visionary. Examples to such sustainable aspects that could be added to the tangible category are the conservation of natural resources, passive designs and recycling. While intangible is indisputably defined as the thing that has no appearance, not touchable, not defined and clear to the mind but it could be observed and identified by sense. Examples to such an aspect includes the conservation of cultural ideas and biophilia (Oxford, 2016).

Several research showed that a daily connection of humans with nature has a high positive influence on humans such as an increase in creativity and the ability to concentrate and it decreases stress and irritability. This daily connection also reinforces the values of respecting, conserving and taking care of nature (Bruno Duarte Dias, 2015). Exposing children to the natural world and teaching them of the importance of environmental sustainability is the key to shaping those children to be better citizens of the world.

Biophilia literally means the love of living things. More advanced, it means that there is an instinctive bond between human and nature. This bond is proved, for example, by the captivate feeling we have when crackling fires and crashing waves. Biophilic design is extended from the meaning of the word Biophilia. The aim of this design is to integrate nature into spaces for connecting human to nature. This design is recognized after finding out the highly positive impact nature could have on human health, education, creativity and wellbeing (Bruno Duarte Dias, 2015).

\section{Research Problem}

Nowadays Children have no respect and appreciation for nature and its value due to being detached from it by spending most of their times indoors, where most of those indoor areas are full of manmade and artificial materials. In the late 20 th century and early 21 st century, this problem was widely spread out all over the world due to the release of technology that attracts humans, especially children, attentions. Such technologies that attract children are video games, TV's, computers, etc.

In general, individuals in the western society spend around $90 \%$ of their time indoors (Roberston, 2014). In addition, lately a survey was conducted on 12,000 parents from 10 different countries. The result of the survey shows that one- 
third of children in the age between the ages of 5 to 12 years spent less than 30 minutes every day outside (Martinko,2016).

Classrooms are mostly designed with manmade objects and rarely where you could find anything related to nature, not even daylight. This created a big gap between children and nature. Nowadays they always choose artificial, manmade objects rather than choosing natural ones. For example, children prefer going to swimming pools rather than going to sea although both are located near each other. This is due to the lack of experience they had with nature so they do not feel the positive effect of nature on them and they do not notice the difference of being connected to nature than to manmade objects. Consequently, this research will investigate the techniques of creating a space that will link children and nature to educate them about sustainability.

\section{Research Objective}

This paper's aims to create a guidelineor criteria of sustainability principles for architects to follow. Those guidelines are formed to produce a sustainable, nature-interactive educational space. This is for embedding sustainability principles in the mindset of children and for reconnecting children to nature.

Human behavior affects the environment in a negative way and this shows that humans are not aware of how the status of the environment could affect us. For this reason, humans should get reconnected to nature in order to respect it and understand it and they should be aware of sustainability and how nature could be preserved. The specific category of humans that this should be applied to is children. As Frederick Douglass said "It is easier to build up a child than it is to repair an adult". For teaching children about sustainability principles and conservation of nature they should experience those principles and get connected to nature by living in it. This is applied by integrating both sustainability and nature into one of the physical spaces that children spend most of their time in, which is school.

Forming a sustainability guideline and criteria to have a nature interactive educational space through 3 different phases that are illustrated in figure (2).

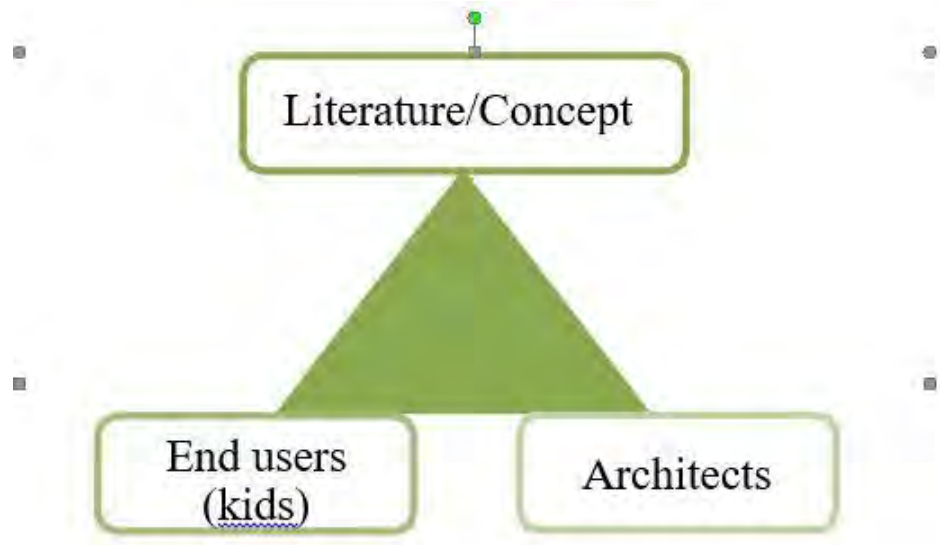

Figure 2: Participants Group in Designing the Educational Physical Space, (Source: author after extant literature, 2016)

\section{Research Questions}

- What needs to be done to have a respectful generation that is aware of the benefits and the value of nature?

- How are tangible and intangible sustainability aspects are applied and what are their techniques?

- What is the role of an architect in producing a generation that is aware of the value and importance of nature?

\section{Value of Research}

The importance of this research is the scarcity in research in providing guidelines of integrating nature by sustainable aspects. There also is a noticable gap in research that explains the tangible and intangible concepts of sustainability. In addition, this research topic is a present topic and it is vital as the worldwide is talking about applying sustainability and biophilia in their buildings due to their need of this as a solution to many worldwide problems. 


\section{Methodology}

The research utilized various methods to attain the main objective. Those methods included a literature review that tackled the principles of sustainability and nature into spaces. An analytical study has also been applied on two international case studies.

\section{Defining Sustainability Aspects through Literature Review}

This part of the paper discuss different approaches in literature that dealt with sustainability. Existing literature was reviewed including research papers that explain different general aspects of sustainability such as passive techniques. Those papers also discuss the sustainability aspects that are integrated into educational spaces such as the site aspect and the arrangement of classrooms and its furniture (flexibility) and finally, the research papers define biophilia and its relation to sustainability.

In the period from 2010 to 2017 , most of the research papers are published and a few were published before 2010 . This shows that sustainability is a topic that was onluy recently revived. This statistic is shown in fig. (3).

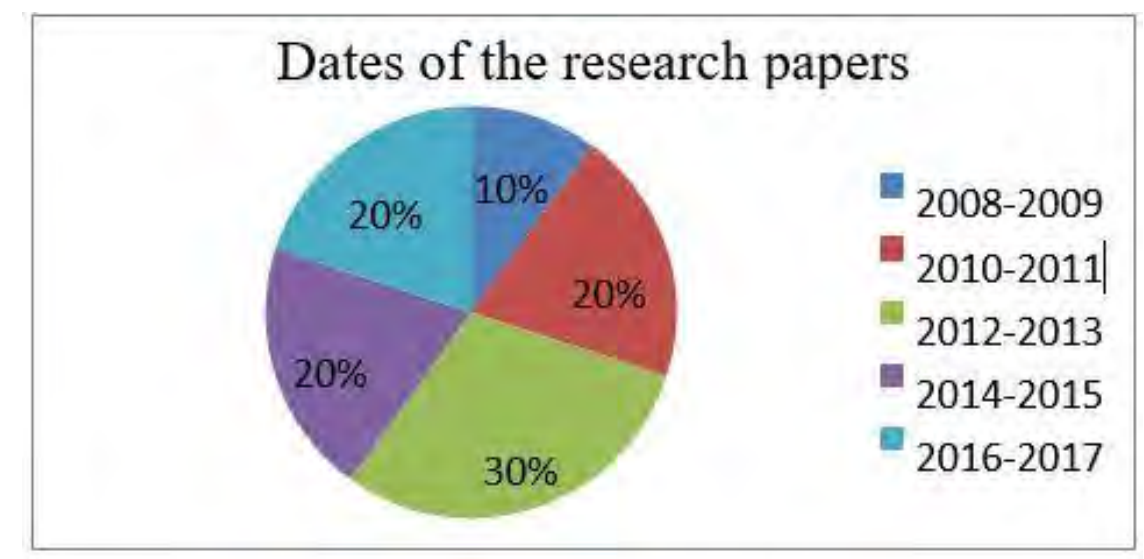

Figure 3: Pie Chart on the Percentage of the Research Papers'Dates, (Source: author after extant literature, 2016)

Fig. (4) Shows that most of the research papers that were published were from developed countries and that clarifies and proves the importance of conserving the environment and the keeness of developed countries to sustain their quality of life compared to developing countries.

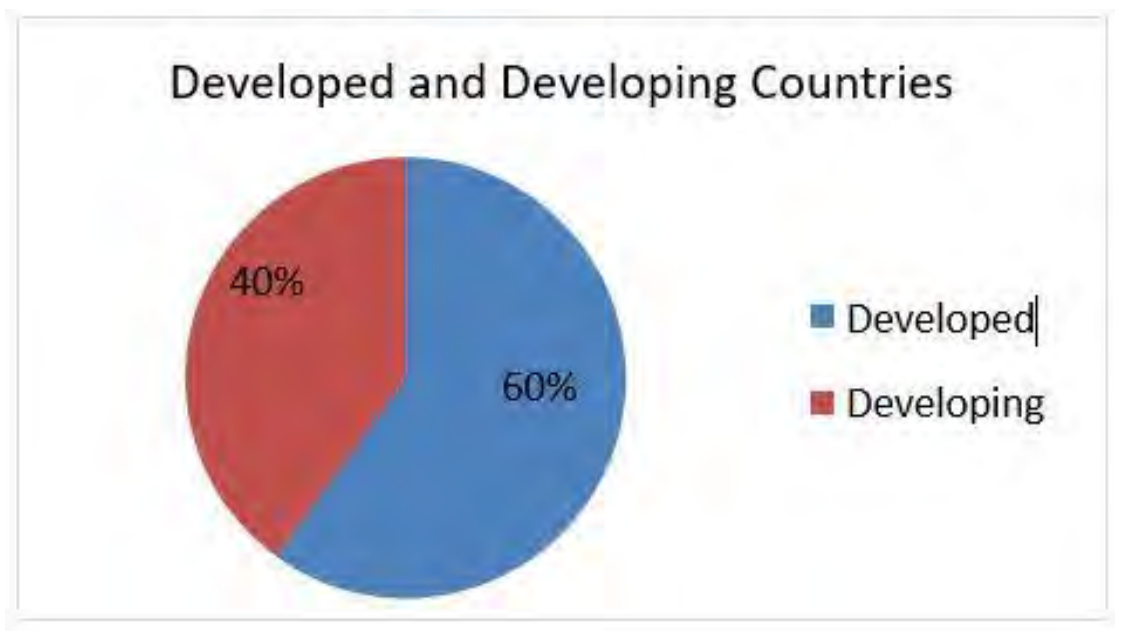

Figure 4: Pie chart on the percentage of the developed and developing countries, (Source: author after extant literature, 2016) 
Biophilia is one of the intangible sustainability aspects that means the love of living things. In the next section, the aspects and principles of sustainability and biophilia will be identified.

\section{Summary of Sustainability Aspect in Literature Review}

Sustainability has 3 main pillars, each pillar has different aspects under it. Those aspects could be classified into tangible and intangible. Table (1) mention the principles of one of the important tangible aspects that is discussed by (Suresh B. Sadineni; Srikanth Madala and Robert F. Boehm, 2011).

Table 1.Principles of the Aspect "Passive Building Envelope"

\begin{tabular}{|c|c|c|}
\hline Year/Author & Sustainability Aspect & Principles of the Aspect \\
\hline $\begin{array}{l}2011 \\
\text { Suresh B. Sadineni; } \\
\text { Srikanth Madala } \\
\text { Robert F. Boehm }\end{array}$ & Passive building envelope & 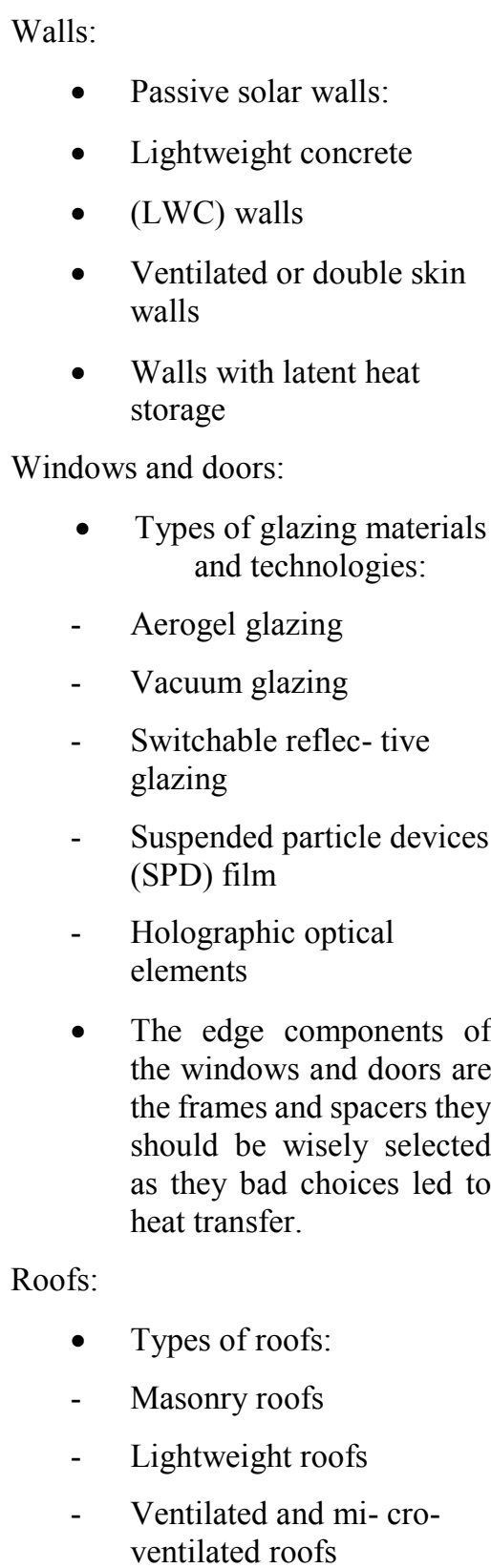 \\
\hline
\end{tabular}




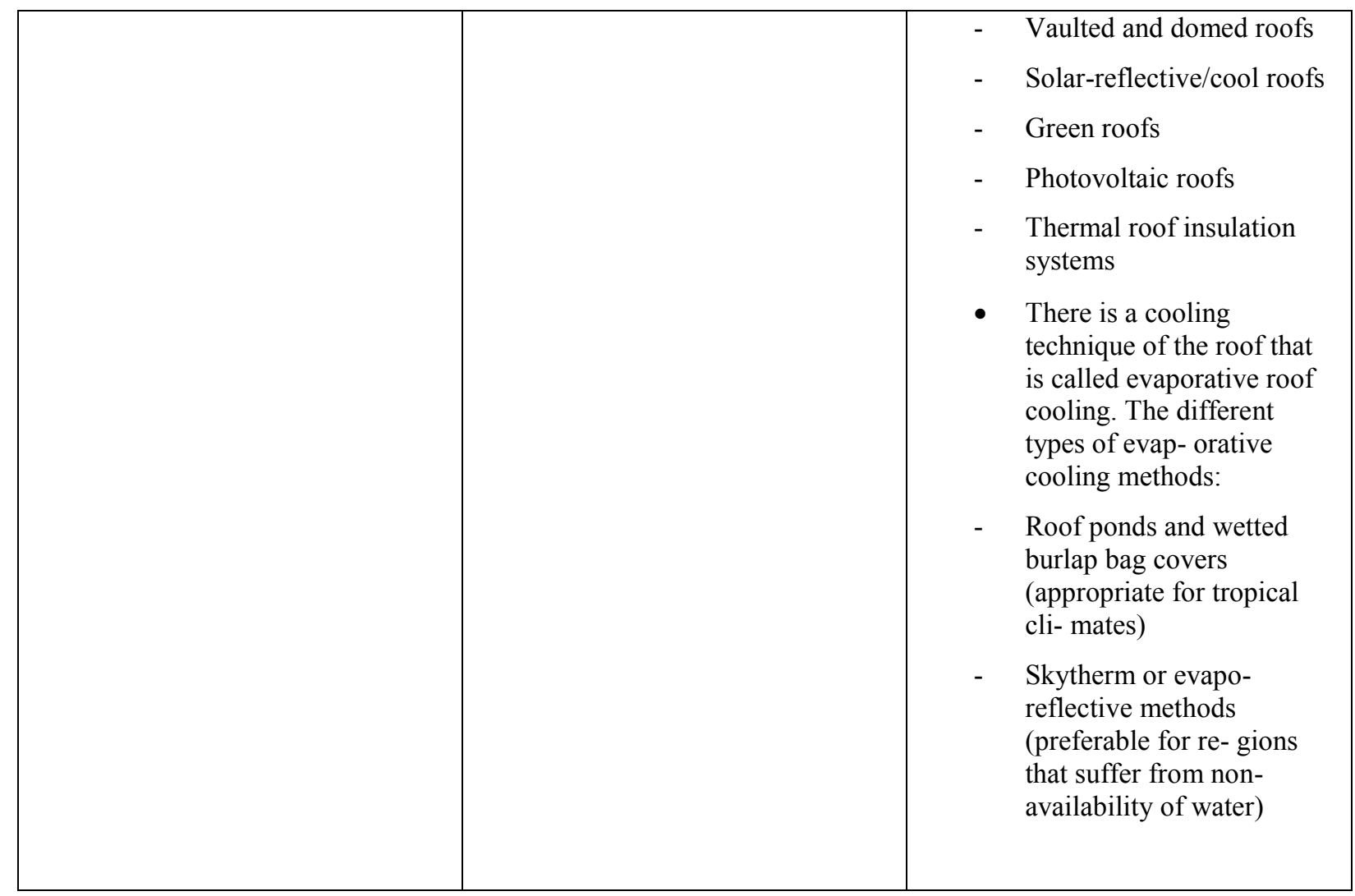

Source: author after extant literature, 2016

\section{Sustainability Aspects Related to Educational Spaces:}

"Architecture as pedagogy" (Orr, 1993), a phrase that describes the capability of learning from buildings and not only in it. This is done by integrating sustainability to buildings in which we spend most of our time. Schools are one of the most places that children spend their time in. That is why fig. (5) illustrates that most of the research papers mention sustainability within educational spaces.

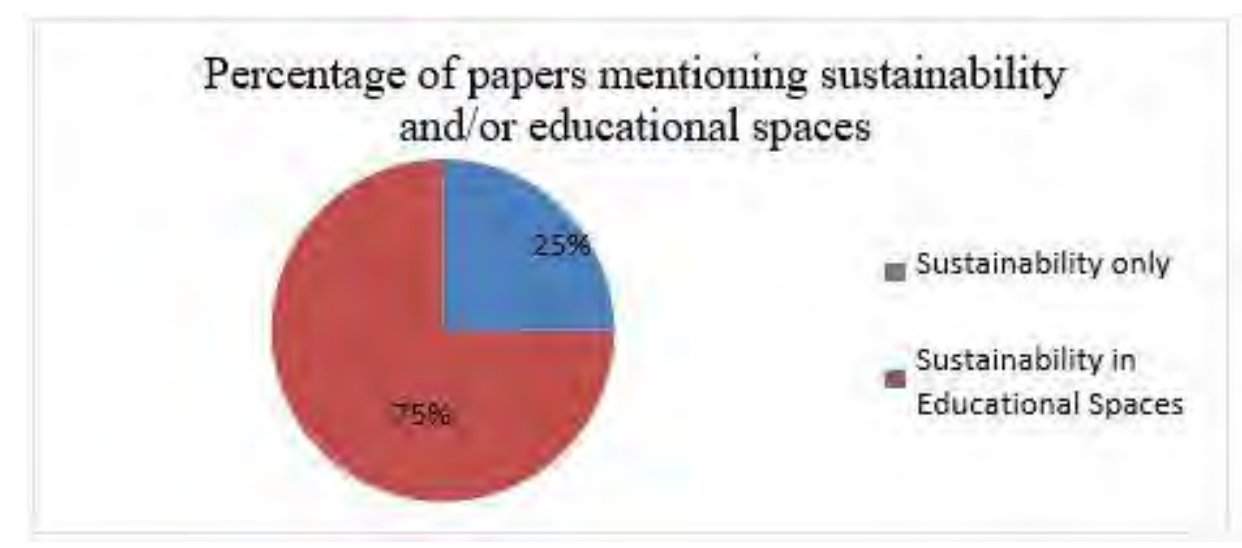

Figure 5: Pie Chart of the Percentage of Papers Mentioning Sustainability and/or Educational Spaces, (Source: author, after extent literature)

The sustainable aspect that mostly has been discussed is biophilia and its idea of integrating nature to physical spaces. However, (Seda Tounk and Kutlu Sevinc Kayihan, 2012) and (Ahmed Elseragy; Amira Elnokaly and Mohammed 
Gabr, 2011) discussed 2 other aspects of sustainability. Figure (6) shows the percentage of papers that discussed the aspect of biophilia compared to the other aspects.

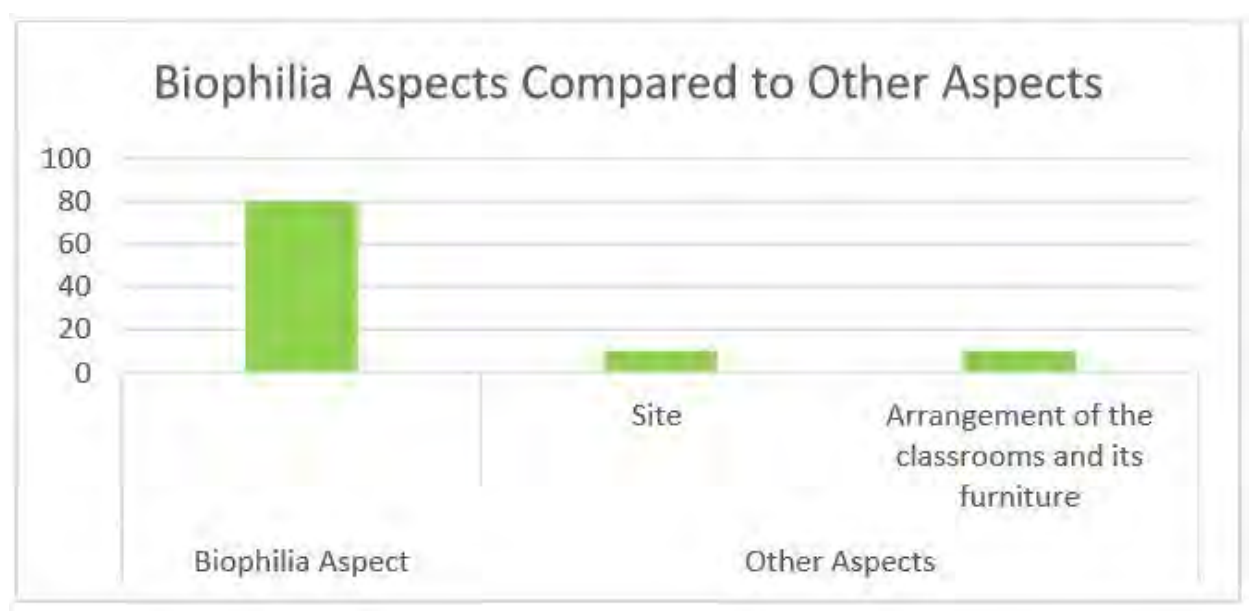

Figure 6: Column Chart showing the Percentage of Papers that Discussed the Aspects of Biophilia Compared to the other Aspects, (Source: author after extent literature, 2016)

The way of implementing biophilia into physical spaces was different from one research paper to another with some similarities in some of the points. However, all of those ways of implementation could be summarized into (Kellert, S, J. Heerwagen and M. Mador, eds, 2008) six elements of biophilic design. Figure (7) shows those six elements and their attributes.

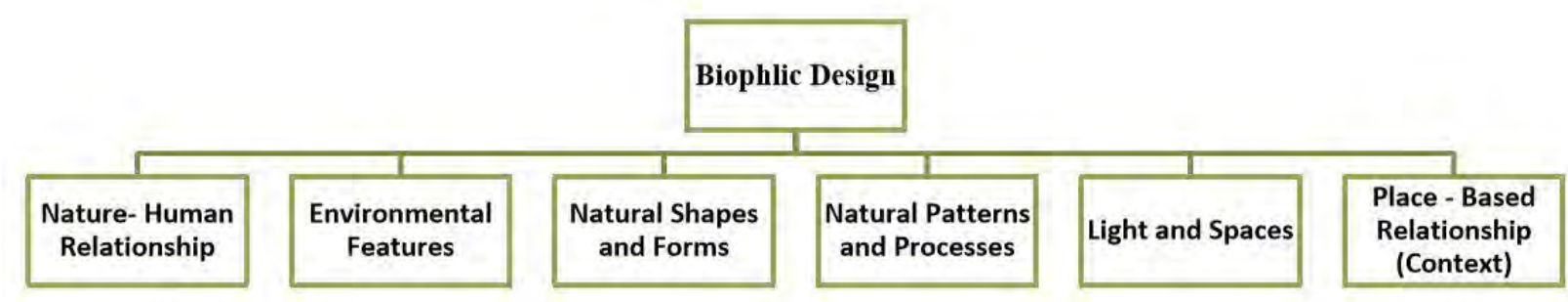

Figure 7: Kellert 6 Elements of Biophilic Design and their Attributes, (Khodier \& Habib, 2016)

Table 2. mention the other sustainability aspects that are related and should be implemented on educational spaces.

\begin{tabular}{|c|c|c|}
\hline Year/author & Sustainability Aspects & Principles of the Aspect \\
\hline $\begin{array}{c}2012 \\
\text { Seda Tonuk and Kutlu } \\
\text { Sevinc Kayihan }\end{array}$ & School Site & $\begin{array}{l}\text { Types of transportation: } \\
\text { - Using sustainable transportation such as buses, } \\
\text { rail, walk- ing or cycling. } \\
\text { - } \quad \text { Using Human pow- ered transportation such as } \\
\text { bicycle or scooter } \\
\text { Parking: } \\
\text { - Reducing parking area } \\
\text { - Preffered parking ( } 5 \% \text { of total parking area) for } \\
\text { low emmis- sion vechicles } \\
\text { - Locating parking ar- eas out of the school } \\
\text { gardens and distant from classrooms }\end{array}$ \\
\hline
\end{tabular}




\begin{tabular}{|c|c|c|}
\hline & & 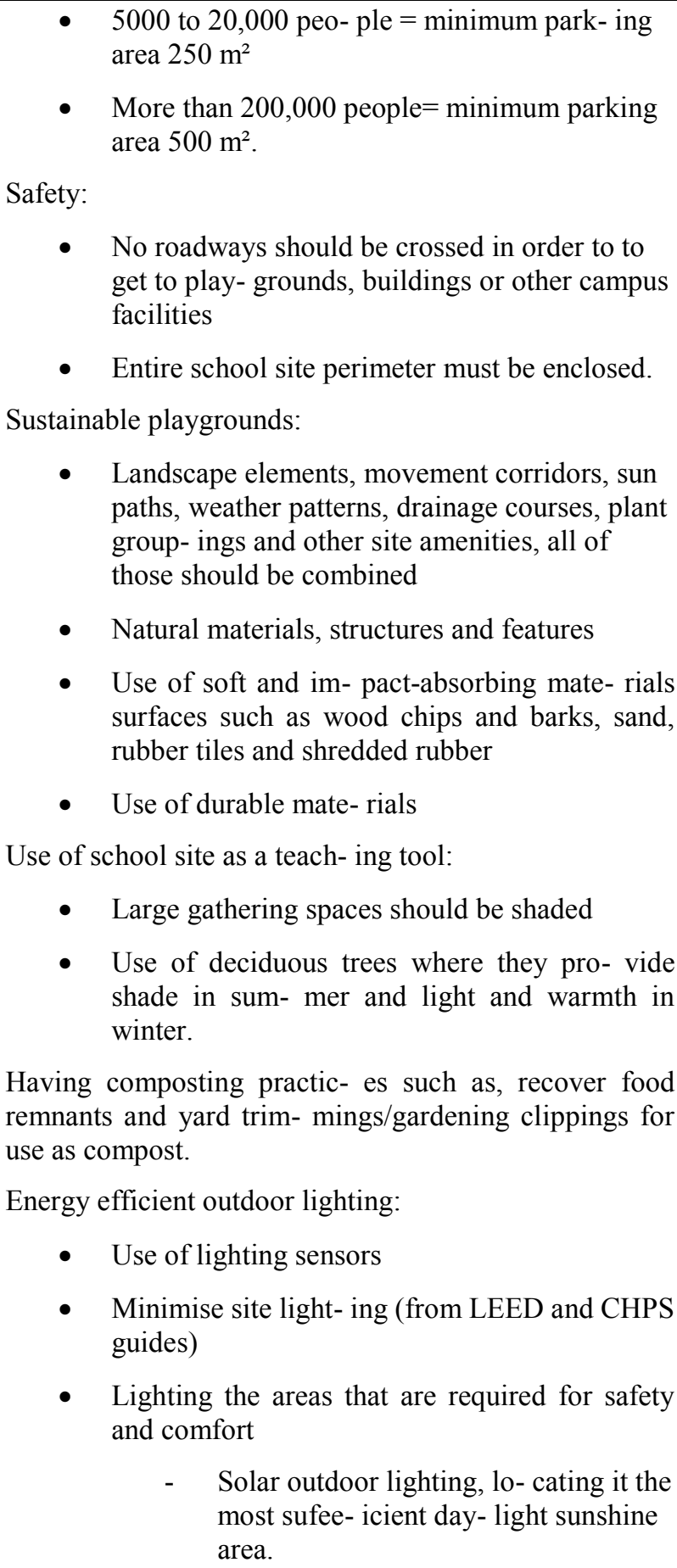 \\
\hline $\begin{array}{l} \\
\end{array}$ & $\begin{array}{l}\text { Arrangement of the } \\
\text { classrooms and its } \\
\text { furniture }\end{array}$ & $\begin{array}{l}\text { A sustainable classroom is not only of hav- ing natural } \\
\text { day lighting, ventilation and having comfortable space } \\
\text { without destroy- ing the environment and consuming it. } \\
\text { Sus- tainability is also to have a flexible space that is } \\
\text { capable of being changed in future and allows various } \\
\text { activities to be held in without cost or inconvenience. } \\
\text { Figure (6) shows an example of a flexible eco-class }\end{array}$ \\
\hline
\end{tabular}




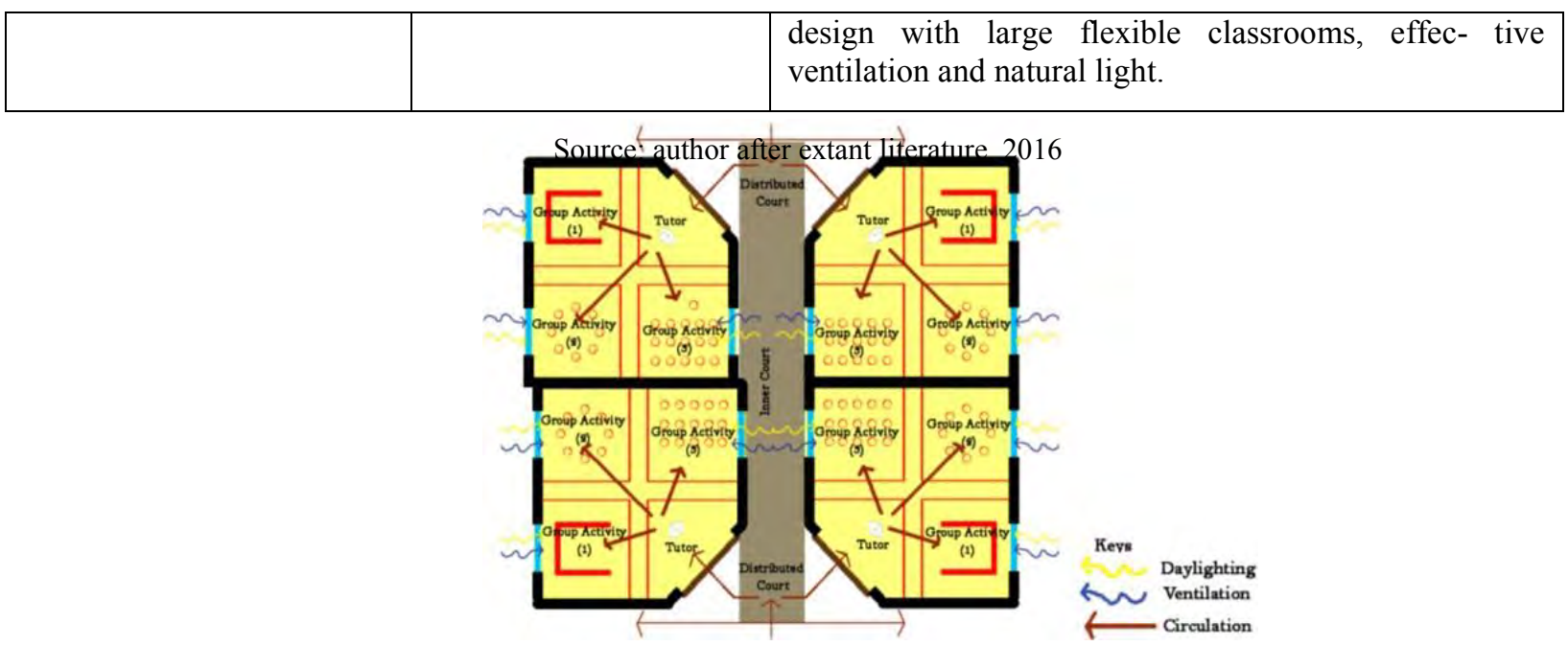

Figure 8: A Prototype of a Flexible Eco-class Design, (Source: author after extent literature, 2016)

\section{Relation between Biophilia and Sustainability:}

Biophilia means the love of living things. Furthermore, that means humans are originally in love with nature. Due to the connection of biophilia and nature, Figure (7) illustrates that most of the papers give a hint that biophilia should be added under the environmental sustainability pillar as it works with integrating nature to physical spaces. Nevertheless, a convincing opposite opinion was proposed by (Dias, BEYOND SUSTAINABILITY - BIOPHILIC AND, 2015) who claimed that biophilia could also be found under the economic sustainable pillar and that is due to biophilia's effect in improving the performance of humans and that would increase the income of the building the physical space if it was a profitable physical space. In my opinion, biophilia falls in both the two pillars but it is mainly related to the environmental sustainability pillar.

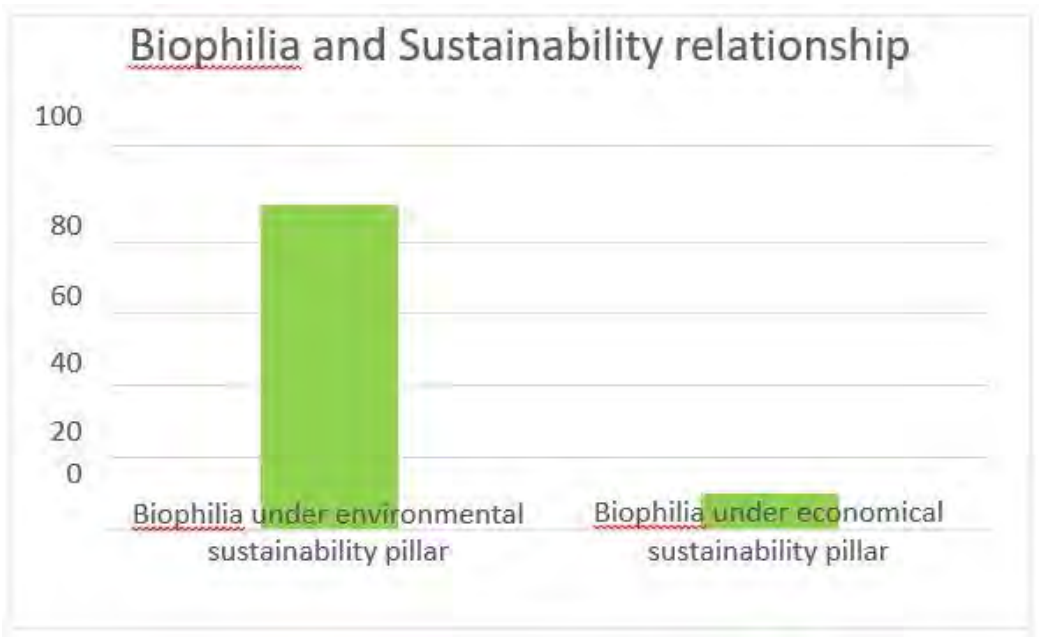

Figure 9: Column Chart of the Percentage of Research Papers that add Biophilia under Environmental or Economical Sustainability Pillars, (Source: author, after extent literature)

\section{Analysis of International Examples}

As mentioned before, biophilia is one of the intangible sustainability aspects. According to recent studies, integrating biophilia in educational spaces improves the performance of children in studying and increasing their creativity. Also applying biophilia on buildings reconnect children to nature and teach them about sustainability. This part of the paper consists of an analytical study on international educational spaces that has sustainability aspects. One of the 
sustainability aspects that is applied is biophilia, where nature is integrated with the project. The case studies are analysied according to a criteria created from the findings of the literature review.

\section{Nature and Environmental Learning Center (NME)}

This case study is located in Amsterdam. The aim of the project is to serve as a learning space and an educational tool where it teach stu- dents about environment, sustainability and gardening. Table (3) il- lustrate many of the sustainability principles and biophilic design principles that have been applied on the building. The sustainability principles are clarified in figure (10).

Table 3.Biophilic and Other Sustainability Aspects principles in the Case Study (Wang, 2015)

\begin{tabular}{|c|c|}
\hline \multicolumn{2}{|c|}{ Principles of Biophilic Aspect } \\
\hline Greenery & $\begin{array}{l}\text { - The building is surrounded by verdant garden } \\
\text { - The north façade is fully glazed to have a frame } \\
\text { view of the garden }\end{array}$ \\
\hline Playgrounds & - The playground is a garden full green \\
\hline Outdoor Class- rooms/Learning areas & $\begin{array}{l}\text { - The outdoor garden is used for teaching about } \\
\text { gardening }\end{array}$ \\
\hline Site & - The building is placed into a green area. \\
\hline Pets/ Animals & $\begin{array}{l}\text { - } 20 \text { birdhouses are placed on the exterior east } \\
\text { wall. } \\
\text { - A nook for a bat is placed on the exterior West } \\
\text { wall. }\end{array}$ \\
\hline \multicolumn{2}{|c|}{ Principles of other Sustainability Aspects } \\
\hline Shape and Form & $\begin{array}{l}\text { - The form consist of a slanted roof. } \\
\text { - This slat is carefully placed on the site to help } \\
\text { achieve optimal solar orientation and gives } \\
\text { children the chance to see solar panels up close. }\end{array}$ \\
\hline Material & $\begin{array}{l}\text { - Wood used in the interior space was left } \\
\text { untreated to reinforced the connection with } \\
\text { nature. }\end{array}$ \\
\hline Lighting & $\begin{array}{l}\text { - The north facade is fully glazed to bring in } \\
\text { natural light }\end{array}$ \\
\hline Ventilation & - Cross-ventilation \\
\hline $\begin{array}{l}\text { Renewable energy/ } \\
\text { Passive techniques }\end{array}$ & $\begin{array}{l}\text { - There is solar-powered structure's energy- } \\
\text { efficient features on the building. They were } \\
\text { designed to be highly visible and tangible. }\end{array}$ \\
\hline
\end{tabular}




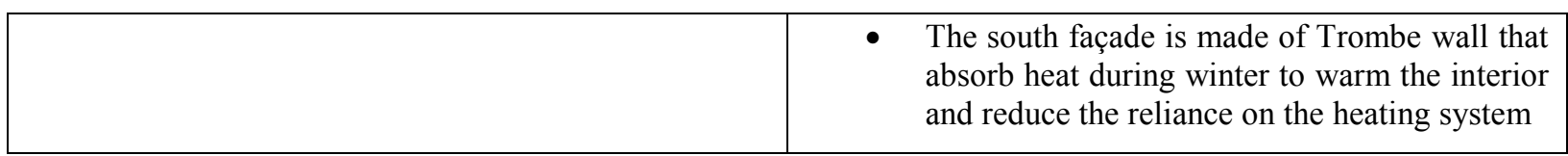

Source: author after extant literature, 2016
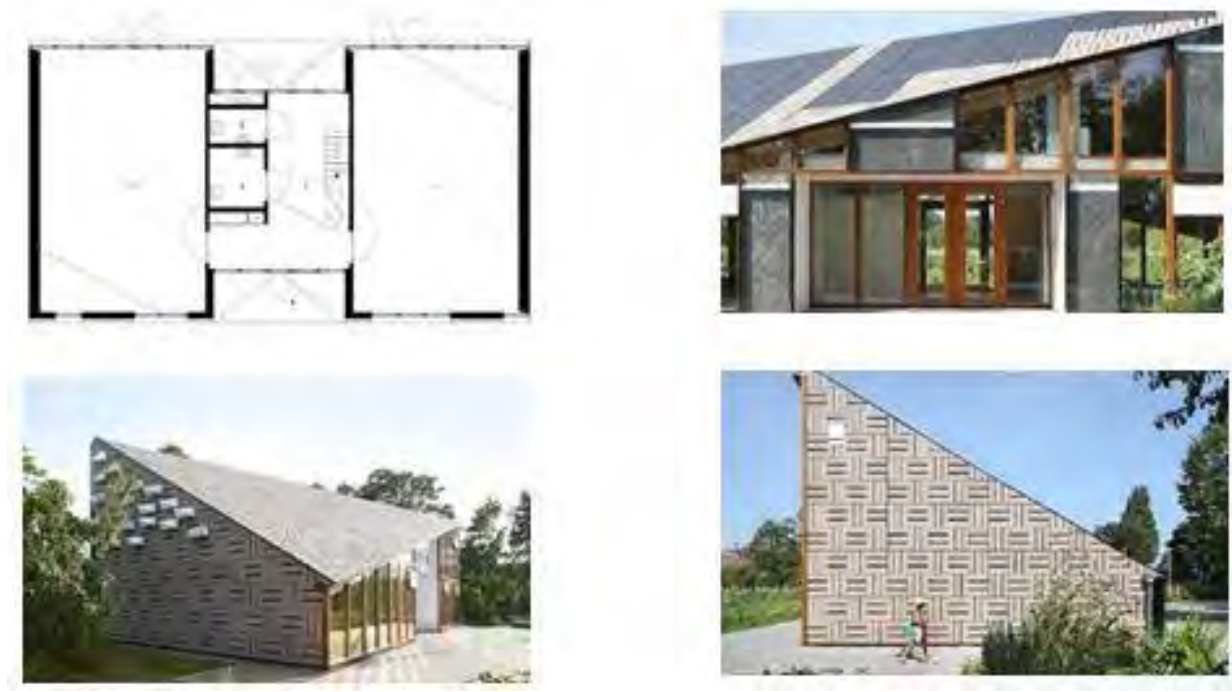

Figure 10: (Left-Top) the cross-ventilation where there are openings in the opposite sides of the building - (Right- Top) the solar panels, (Left - Bottom) birdhouses, (Right - Bottom) nook (Wang, 2015)

\section{The Green School}

The case study is located in Indonesia, Bali. This case study shows the role of the architect in teaching sustainability. Where the aim of the designers and the environmentalists John and Cynthia Hardy, who designed this sustainable school, was to encourage communities to live sustainably. This building has a high connection with the environment that the result of the building is that it produced a holistic green community that causes children to be more engaged with the environment and educate them to be more curious and passionate about plant and the environment. Table 4 and figure (11) shows how this school was built sustainably and how was it built to motivate people about sustainability.

Table 4.Biophilic and Other Sustainability Aspects principles in the CaseStudy (ArchDaily, 2010)

\begin{tabular}{|c|c|}
\hline \multicolumn{2}{|c|}{ Principles of Biophilic Aspect } \\
\hline Greenery & $\begin{array}{l}\text { - The building is located within green area that } \\
\text { from every point in the building there is a } \\
\text { view to green space. }\end{array}$ \\
\hline Playgrounds & $\begin{array}{l}\text { - Green open space playground that is } \\
\text { surrounded by long trees of the jungle. }\end{array}$ \\
\hline Outdoor Classrooms/Learning areas & $\begin{array}{l}\text { - The whole building has no walls } \\
\text { - Sails are used when needed to keep out wind } \\
\text { and rain. This is said to be controlling the } \\
\text { climate which is opposite to climate control. }\end{array}$ \\
\hline
\end{tabular}




\begin{tabular}{|c|c|}
\hline & $\begin{array}{l}\text { Rice paddies where kids learn to how to grow } \\
\text { rice. }\end{array}$ \\
\hline Site & $\begin{array}{l}\text { - Located within a jungle that is rich with native } \\
\text { plants and trees. } \\
\text { - Located next to sustainable organic gardens. }\end{array}$ \\
\hline \multicolumn{2}{|l|}{ Pets/ Animals } \\
\hline \multicolumn{2}{|c|}{ Principles of other Sustainability Aspects } \\
\hline Shape and Form & $\begin{array}{l}\text { - The form of the roof in the layout view is } \\
\text { organic. Where it is taking the form of three } \\
\text { nautili spiraling in- to one another }\end{array}$ \\
\hline Material & $\begin{array}{l}\text { - The whole building was construct of liner } \\
\text { meters of bamboo without the use of heavy } \\
\text { machinery. } \\
\text { - Traditional mud used for walls } \\
\text { - Local grass are used as building material. }\end{array}$ \\
\hline Lighting & $\begin{array}{l}\text { Due to the absence of walls there is plenty of } \\
\text { natural light in the build- ing for daytime. } \\
\text { - A } 3.75 \mathrm{~m} \text { skylights at the top of each tower. }\end{array}$ \\
\hline Ventilation & $\begin{array}{l}\text { - The orientation of the building causes both the } \\
\text { wet and dry sea- son winds to cool the people } \\
\text { inside the building. }\end{array}$ \\
\hline Renewable energy/ Passive techniques & $\begin{array}{l}\text { - Bamboo sawdust hot water and cooking } \\
\text { system. } \\
\text { - Hydro-powered vortex generator. } \\
\text { - Solar panels. }\end{array}$ \\
\hline
\end{tabular}

(ArchDaily, 2010) 

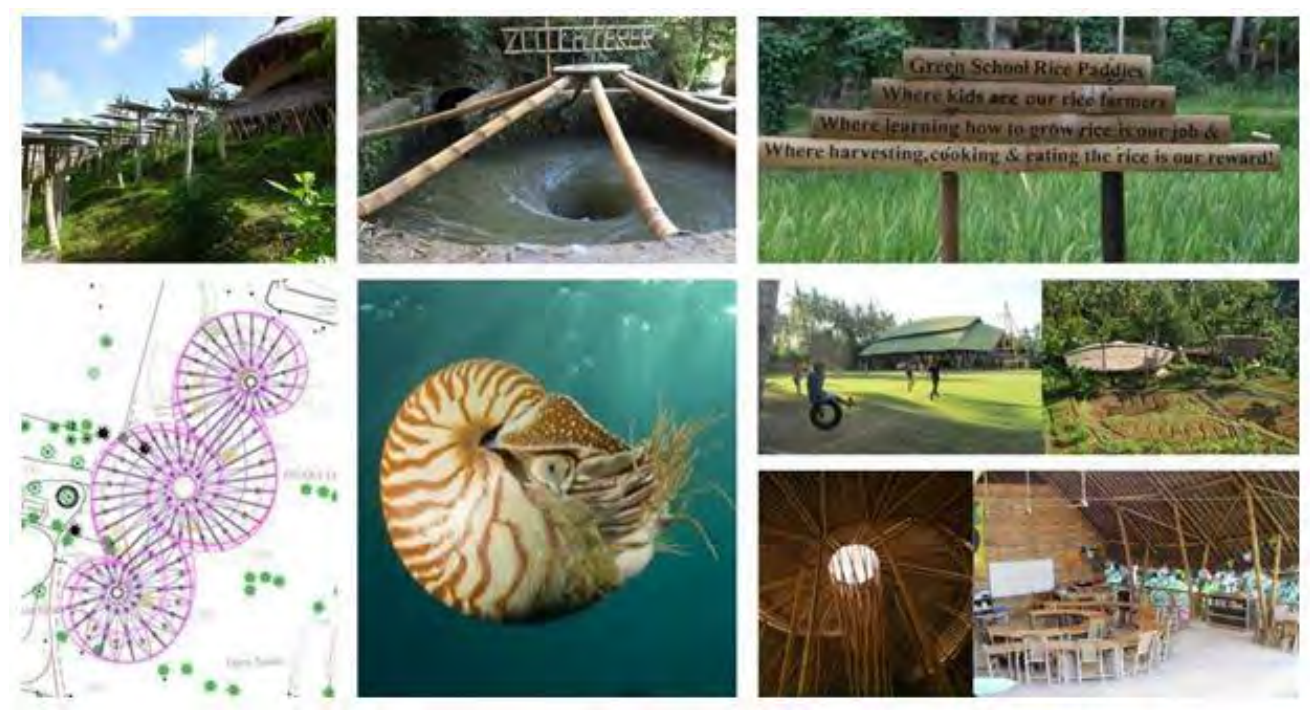

Figure 11: (Left-Top) Solar Panels, (Center-Top) Hydro-powered vortex generator, (Right-Top) Rice Farms, (Bottom-Left) School Layout and its roof form inspired from the nautili, (Center-Right) Open green playgrounds and organic gardens, (Bottom-Right) Natural light, ventilation and the material bamboo. (ArchDaily, 2010) (EcoZine, 2012)

\section{Conclusion}

This paper aimed to investigate the role of architecture in the creation of spaces for children that can act as a tool of teaching in itself, and which could promote both tangible and intangible sustainability concepts. Through the findings of the literature review and the analysed international case studies the objective of the paper was partly tackled as it clarified the sustainability principles that architects could implement in educational spaces to have a sustainable space that act as a teaching tool. The limitation of this paper is in not being able to investigate the effect of the sustainable educational spaces on children on the long-term. Studies cannot be conducted on children if they will keep being aware of sustainability and applying it in their life or as they get old and away from the space or they will lose the values they had learned from the space. Finally, as science evolves and new technologies get discovered, it is recommended that the produced sustainability guideline should be continuously renewed and investigated in order to keep on having an efficient guideline for architects to follow where some criteria could be added or removed.

\section{Acknowledgement}

The authors are thankful to the Interactive Sustainable Child Day- care Center (ISCDC) project that is part of the Young Investigator Research Grant (YIRG) project at the British University of Egypt (BUE).

\section{References}

1. Dias, B. D., (2015), "BEYOND SUSTAINABILITY - BIOPHILIC AND REGENERATIVE DESIGN IN ARCHITECTURE", European Scientific Journal, $147-758$.

2. Mirmoradi, S. S., \& Mozaffar, F., (2012), "Effective Use of Nature in Educational Spaces Design”, Organization, Technology and Management in Construction Journal, Vol. 4, No. 1, 381-392.

3. Ryan, C. O., Browning, W. D., Clancy, J. O., Andrews, S. L., \& Kallianpurkar, (2014), "BIOPHILIC DESIGN PATTERNS: Emerging NatureBased Parameters for Health and Well-Being in the Built", International Journal of Architectural Research, Vol.8, No. 2, 62-76.

4. Zari, M. P., (2009)," An architectural love of the living: Bio- inspired design in the pursuit of ecological regeneration and psychological wellbeing", In Ed. C.A.Brebbia, Sustainable Development and Planning IV, Southampton, England: Wessex Institute of Technology Publisher pp. 293-302.

5. Elseragy, A., Elnokaly, A., \& Gabr, M. (2011). "Building Sustainable Learning Environments that are 'Fit for the Future' with Reference to Egypt”, In ResearchGate, October, 2011, London, UK.

6. Holtman, A., \& Ryan, K. (2012). "The Biophilic Concept: Framing Learning with Nature”,In Washington State University., EDRA43 2012 , May 2012, Washington, United State of America, School of Design and Construction.

7. Khodier, L., \& Habib, E. (2016). "The Emergent Biophilia, An Exploratory Study on the Impact of Integrating Biophilic Principles Into Designing Educational Spaces for Children”. In SBE16 Cairo Conferenc,2016 ,Cairo, Egypt, SBE16 Cairo.

8. Izadpanahi, P., Tucker, R., \& Elkadi, H. (2015): Greenhouse affect: the relationship between the sustainable design of schools and children"s environmental attitudes, Environmental Education Research, DOI: 10.1080/13504622.2015.1072137 
9. Kayıhan, K. S., \& Tönük, S. (2012): A study on sustainable use of school sites at (primary) eco-schools in Istanbul, Journal of Environmental Planning and Management, DOI:10.1080/09640568.2012.709179

10. Sadineni, S. B., Madala, S., \& Boehm, R. F. (2011). Passive

11. building energy savings: A review of building envelope components. Renewable and Sustainable Energy Reviews 15 , 3617- 3631. DOI: 10.1016/j.rser.2011.07.014

12. Shaimaa El-Ghobashy, G. M. (2016). Improving Sustainability Concept in Developing Countries: Nature Influences on Architecture Interior Designs. Procedia Environmental Sciences 34, 573 - 581. DOI: 10.1016/j.proenv.2016.04.050

13. Barrett, D. (2015, November 18). Retrieved from http://iheartintelligence.com/2015/11/18/children-nature/

14. Bruno Duarte Dias, M. (2015). Beyond Sustainability - Biophilic and Regenerative Design in Architecture. European Scientific Journal, 147158.

15. Dias, B. D. (2015). BEYOND SUSTAINABILITY - BIOPHILIC AND. European Scientific Journal, $147-158$.

16. Dias, B. D. (2015). BEYOND SUSTAINABILITY - BIOPHILIC AND. European Scientific Journal, 147 - 758.

17. Elseragy, A., Elnokaly, A., \& Gabr, M. (2011). Building Sustainable Learning Environments that are „Fit for the Future with Reference to Egypt. ResearchGate. London: ResearchGate.

18. EPA. (2016, Augest 16). EPA US Environmental Protection Agency. Retrieved from About EPA Schools.

19. Hamdan, W. (2013, December 9). Retrieved from http://www.csrwatchjordan.com/blog1/5-of-the-best-csr- practices

20. Holtman, A., \& Ryan, K. (2012). The Biophilic Concept: Framing Learning with Nature. 2012. Washington: Interior Design . School of Design and Construction. Washington State University.

21. Izadpanahi, P., Tucker, R., \& Elkadi, H. (2015, Augest ).

22. Greenhouse affect: the relationship between the sustainable design of schools and children es environmental attitudes.

23. Kayıhan, K. S., \& Tönük, S. (2012). A study on sustainable use of school sites at (primary) eco-schools in Istanbul. Journal of Environmental Planning and Management, 1-15.

24. Khodier, L., \& Habib, E. (2016). The Emergent Biophilia, An Exploratory Study on the Impact of Integrating "Biophilic Principles". SBE16 Cairo Conference. Cairo: SBE16 Cairo.

25. Martinko, K. (2016, March 25). Retrieved from treehugger: http:/www.treehugger.com/culture/children-spend-less-time- outside-prisoninmates.html

26. Mirmoradi, S. S., \& Mozaffar, F. (2012). Effective Use of Nature in Organization, Technology and Management in Construction Journal, 381392.

27. Morris, W. (2016, April 7). Tangible Definitions of Sustainability Increase Engagement. Retrieved from Collective Responsibility: http://www.coresponsibility.com/tangible- sustainability-definitions/Orr, D. W. (1993). Conservation Biology. Island Press/Center for Resource Economics.

28. Oxford. (2016). Retrieved from Oxford University Press:https://en.oxforddictionaries.com/definition/tangible

29. Roberston, M. (2014). Sustainability Principles and Practice. New York: Routledge.

30. Ryan, C. O., Browning, W. D., Clancy, J. O., Andrews, S. L., \& Kallianpurkar, N. B. (2014). BIOPHILIC DESIGN PATTERNS: Emerging Nature-Based Parameters for Health and Well-Being in the Built. International Journal of Architectural Research, 62-75.

31. Sadineni, S. B., Madala, S., \& Boehm, R. F. (2011). Passive building energy savings: A review of building envelope components. Renewable and Sustainable Energy Reviews, 3617- 3631

32. Shaimaa El-Ghobashy, G. M. (2016). Improving Sustainability Concept in Developing Countries, Nature Influences on Architecture Interior Designs. Procedia Environmental Sciences 34, 573 - 581

33. Wang, L. (2015, December 22). Net-zero learning center teaches children about gardening and sustainabiliity . Retrieved

34. from Inhabitat: http://inhabitat.com/net-zero-learning-center- teaches-children-about-gardening-and-sustainability/

35. Zari, M. P. (2009). An architectural love of the living: Bio-inspired design in the pursuit of ecological regeneration and psychological wellbeing. England : ReshearchGate. 